Cahiers $d u$ MONDE RUSSE

\section{Cahiers du monde russe}

Russie - Empire russe - Union soviétique et États indépendants

50/2-3 | 2009

L'Europe orientale, 1650-1730. Crises, conflits et renouveau

\title{
Census books as a source for historical geography
}

Les registres de recensement comme sources pour la géographie historique

\author{
Aleksei A. Frolov
}

\section{(2) OpenEdition}

Journals

Electronic version

URL: https://journals.openedition.org/monderusse/9716

DOI: 10.4000/monderusse. 9716

ISSN: $1777-5388$

\section{Publisher}

Éditions de l'EHESS

Printed version

Date of publication: 15 September 2009

Number of pages: $315-326$

ISBN: 978-2-7132-2260-3

ISSN: $1252-6576$

\section{Electronic reference}

Aleksei A. Frolov, "Census books as a source for historical geography", Cahiers du monde russe [Online], 50/2-3 | 2009, Online since 13 October 2012, connection on 04 September 2022. URL: http:// journals.openedition.org/monderusse/9716 ; DOl: https://doi.org/10.4000/monderusse.9716 


\section{CENSUS BOOKS AS A SOURCE FOR HISTORICAL GEOGRAPHY}

The medieval cadastres [or census books, sing. pistsovaya kniga] are very important sources on Russian history of the late $\mathrm{Xv}^{\text {th }}$-early $\mathrm{XVIII}^{\text {th }}$ centuries. Many contain detailed descriptions of agriculture in entire uezdy [sing. uezd, basic administrative district in $\mathrm{Xv}^{\text {th }}$-early $\mathrm{XVIII}{ }^{\text {th }}$ century Russia, more or less equivalent to a county]; some of them bear data on separate categories of landholding, e.g. the State lands, or the pomest'ja [sing. pomest'e, military fief], others describe different types of taxable objects (e.g. villages deserted after the previous describing). Using data from the census books is very common in historical research: for social and economic history (statistic data from the census books ${ }^{1}$ ), for historical geography (localizing toponyms in census books ${ }^{2}$ ); for genealogy (listing names of landowners

\footnotetext{
1. N.A. Rozhkov, Sel'skoe khoziaistvo Moskovskoi Rusi v XvI veke [Agriculture in Xvi century Muscovy] (M., 1899); A.M. Gnevushev, Ocherki ekonomicheskoi i social'noi zhizni sel'skogo naseleniia Novgorodskoi oblasti posle prisoedineniia Novgoroda $k$ Moskve [Essays on economic and social life of country people after the annexion of Novgorod by Moscow], vol. 1 (Kiev: Korchak-Novitskii, 1915); Ia.E. Vodarskii, Naselenie Rossii v konce XVII-nachale XVIII veka (Chislennost', soslovno-klassovyi sostav, razmeshchenie) [Population of Russia at the end of XVII ${ }^{\text {th }}$ and the beginning of XVIII ${ }^{\text {th }}$ century (numbers, class- and orders-structure, spatial distribution)] (M.: Nauka, 1977); A.L. Shapiro, éd., Agrarnaia istoriia Severo-Zapada Rossii : Vtoraia polovina XV-nachalo XVI V. [Agrarian history of Northwestern Russia : second half of $X V^{\text {th }}$-beginning of $X V I^{\text {th }}$ century] (L.: Nauka, 1971).

2. K.A. Nevolin, "O piatinakh i pogostakh novgorodskikh" [About the Novgorod piatiny (fifth) and pogosty (cantons)], Zapiski Russkogo geograficheskogo obshchestva, vol. 8 (SPb., 1853); A.M. Andriashev, Materialy po istoricheskoi geografii Novgorodskoi zemli: Shelonskaia piatina po pistsovym knigam 1498-1576 gg [Materials for historical geography of Novgorod lands], vol. 1: Spiski selenii [Villages lists] (M., 1914); Iu.V. Got'e, Zamoskovnyi krai v XVII v. Opyt issledovaniia po istorii ekonomicheskogo byta Moskovskoi Rusi [Trans-Moskva region in XVII ${ }^{\text {th }}$ century. Essay on economic life in Muscovy] (M., 1906), (2d ed., 1937); M.V. Vitov Istoriko-geograficheskie ocherki Zaonezh'ia XVI-XVII VV.: iz istorii sel'skikh poselenii [Essays on the historical geography of the Trans-Onega region, $X V I^{t h}-X V I I^{\text {th }}$ century] (M.: Izd. Moskov. univ., 1962); V.L. Ianin, Novgorod i Litva : Pogranichnye situacii XIII-XV vekov [Novgorod and Lithuania : frontier situations, $X I I I-X V^{\text {th }}$ centuries] (M.: Izd. Moskov. univ., 1998); A.A. Selin, Istoricheskaia geografiia Novgorodskoi zemli V XVI-XVIII VV. Novgorodskii i Ladozhskii uezdy Derevskoi piatiny [Historical geography of Novgorod lands in $\mathrm{XVI}^{t^{t h}}-\mathrm{XVIII}{ }^{t^{t h}}$ centuries. Novgorod and Ladoga districts in the Dereva piatina] (SPb.: D. Bulanin, 2003).
} 
nd other dwellers ${ }^{3}$ ); for comments on historical documents (looking for toponyms, description of estates, income from peasant farms, etc. ${ }^{4}$; for cadastral history (chronology of census books, their types and contents ${ }^{5}$ ).

If works based on census books are numerous, studies about their value as historical sources are paradoxically very rare. ${ }^{6}$ Analysis basically concentrates on how toponyms are listed in the book, on the order and collation of quires in the manuscript, on paper watermarks, on handwritings and their specificities. To these well-known methods we can add another one - an analysis of geographical information [hereafter: GI]. In a vast majority of cases, the primary objective of the census book is the description of settlements and deserted villages (sing. pustosh ). Every such place had a name, which can help us to determine a locality's geographical position by its correlation with toponyms in historical maps. Besides this obvious path of inquiry, there is another promising particularity of the census books: different parts of the text, which follow each other in what seems to be a purely casual order, are in fact connected by spatial proximity. Since the matter in the books was not rearranged by the surveyors at any one of the ulterior stages of their work, it provides the researcher with usable evidence. In this sense the GI is an informational field all by itself, independently of the source it comes from. This dual nature of the GI makes it especially valuable. We intend to illustrate some

3. V.L. Ianin, Novgorodskaia feodal'naia votchina [Feudal landownership in Novgorod] (M.: Nauka, 1981).

4. S.Z. Chernov "Istoricheskaia geografiia Vzvadskogo pogosta" [Historical geography of the Vzvadsk pogost] in I.Ia. Frojanov, ed., Genezis i razvitie feodalizma v Rossii: problemy sotsial'noi i klassovoi bor'by [Feudalism in Russia: origins and development] (L.: Izdat. Leningradskogo Universiteta, 1985), 104-112; E.N. Nosov, "Novgorodskaia volost' Buicy (Istorikoarkheologicheskii kommentarii)" [The Novgorod rural volost' (canton) of Buicy (historical and archaeological commentary)] in Vspomogatel'nye istoricheskie discipliny [Auxiliary sciences of history], vol. 25 (SPb., 1994), 41-56 ; I.Iu. Ankudinov, "Istoriko-geograficheskii kommentarii k novgorodskoi berestianoi gramote $n^{\circ} 390$ " [Historical and geographical commentary on the Novgorod birch bark letter $\mathrm{n}^{\circ}$ 390] in V.L. Ianin, A.A. Zalizniak, Novgorodskie gramoty na bereste (iz raskopok 1990-1996 gg.): paleografiia berestianykh gramot i ikh vnestratigraficheskoe datirovanie [Novgorod birch bark documents (from 1990-1996 excavations): paleography and extra-stratigraphical dating of birch bark documents] (M.: Russkie slovari, 2000), 123-132.

5. D.Ia. Samokvasov, Arkhivnyi material. Novootkrytye dokumenty pomestno-votchinnykh uchrezhdenii Moskovskago gosudarstva XV-XVII stoletii [Archival material. New-found documents from administrations supervising landholding in $X V^{\text {th }}-X V I I^{\text {th }}$ centuries Muscovy] (M., 1905); S.B. Veselovskii, Soshnoe pis'mo. Issledovanie po istorii kadastra i pososhnago oblozheniia Moskovskago gosudarstva [Cadastral surveys. Research on cadastral history and tillagebased taxation in Muscovy], vol. I-II, M., 1915-1916; E.I. Kolycheva, Agrarnyi stroi Rossii XVI veka [Agrarian structures in XVI ${ }^{\text {th }}$ century Russia] (M.: Nauka, 1987).

6. A.M. Andriashev, "O neobkhodimosti predvaritel'nogo izucheniia tekstov pistsovykh knig" [About the necessity of a preliminary study of texts from census books], Russkii istoricheskii zhurnal, vol. 1 (Petrograd, 1917), 109; V.B. Pavlov-Sil'vanskii, Pistsovye knigi Rossii Xvi V.: Problemy istochnikovedeniia i rekonstrukcii teksta [Census books in Xvi century Russia: source assessment and text reconstruction problems] (M.: Nauka, 1991); L.V. Milov, M.B. Bulgakov, I.M. Garskova, Tendencii agrarnogo razvitiia Rossii pervoi poloviny XVII stoletiia: istoriografiia, kompiuter i metody issledovaniia [Evolutionary trends of Russian agrarian history during the first half of XVII ${ }^{\text {th }}$ century: historiography, computer and methodology of research] (M.: Izdat. Moskovskogo universiteta, 1986). 
possible ways of using the GI through a source study, focusing on four examples related to Novgorod census books of the $\mathrm{Xv}^{\text {th }}-\mathrm{XVI}^{\text {th }}$ centuries. All belong to a large area in Northwestern Russia, the "Dereva piatina,"7 a part of the Novgorod country, which included the space between the Msta and the Lovat' rivers.

1. The localization of places mentioned in the census books can show on what principles the work was distributed among several surveyors [sing. pisets ${ }^{8}$ ]. We know that the main amount of work in Dereva piatina during the large surveying campaign (valovoe pis' $\mathrm{mo}^{9}$ ) of the late 1530's was made by Grigorii Morozov and Zhikhor' Riabchikov. We have used some additional sources of the middle of the $\mathrm{XVI}^{\text {th }}$ century to establish a comprehensive index of the pogosty in Dereva piatina's, ${ }^{10}$ correlating them with the individual pisets who worked there. ${ }^{11}$ As a result a map has been made (Fig. 1), which allows us to conclude that the "Big Moscow Road,' which led from Moscow to Novgorod (through Tver' and Vyshnii Volochek), served as a border between the respective surveyors' areas.

2. The GI study helps to evaluate the degree of preservation of surveying materials and to represent clearly on a map the correlation between data lost and preserved. It's important mainly for the manuscripts where the gaps are extensive. For example the census books by Grigorii Morozov and Zhikhor' Riabchikov of the early 1540's have been preserved but fragmentarily. The map of settlements mentioned in the parts now extant of these books demonstrates clearly that the materials concerning the centre, as well as the south-east and south-west of the piatina, have been totally lost (Fig. 2).

The next two examples show the results of a more complicated analysis of the GI, viz. a comparison between the position order of separate settlements (or groups of settlements) in the text of the source on the one hand and in real space

7. Piatina [plural piatiny] means the "fifth part" of Novgorod country, a division which appeared at the end of the $\mathrm{Xv}^{\text {th }}$ century, after Novgorod the Great had been included in Muscovy. Besides the Dereva piatina, there were four other "fifths": the Bezhetsk, Obonezh'e, Shelon' and Vod' piatiny. Each piatina was surveyed independently and had its own census books and other documents concerning land ownership and income.

8. A pisets [plural pistsy], or surveyor, was a government official appointed to work with local communities on the survey and measure of their lands.

9. It was a cadastral campaign which surveyed all the types of landownings, all over the territory of a given region.

10. A pogost is a rural subdivision of the district in Novgorod country. Its territory depended, as far as farming and administration were concerned, from a village which was also named "pogost."

11. A.A. Frolov, "Struktura pistsovykh knig Derevskoi piatiny 1540-h gg. po dannym kompleksa istochnikov konca XV-serediny XVI veka" [Structure of the census books of the 1540 's of the Dereva piatina, according to sources from the end of $\mathrm{xV}^{\text {th }}$ to the middle of $\mathrm{XVI}^{\mathrm{th}^{\text {th }}}$ century], Drevniaia Rus'. Voprosy medievistiki, n²4, 2007, p. 69-79. The areas allotted to each pisets are not exactly the same as the polupiatiny [half fifths]. The former were administrative divisions of the piatina, named after the two surveyors ("Grigorii Morozov's half", "Zhikhor" Riabchikov's half"); polupiatiny were first mentioned in the documents of the 1570's and remained in existence until the XVIII ${ }^{\text {th }}$ century. 


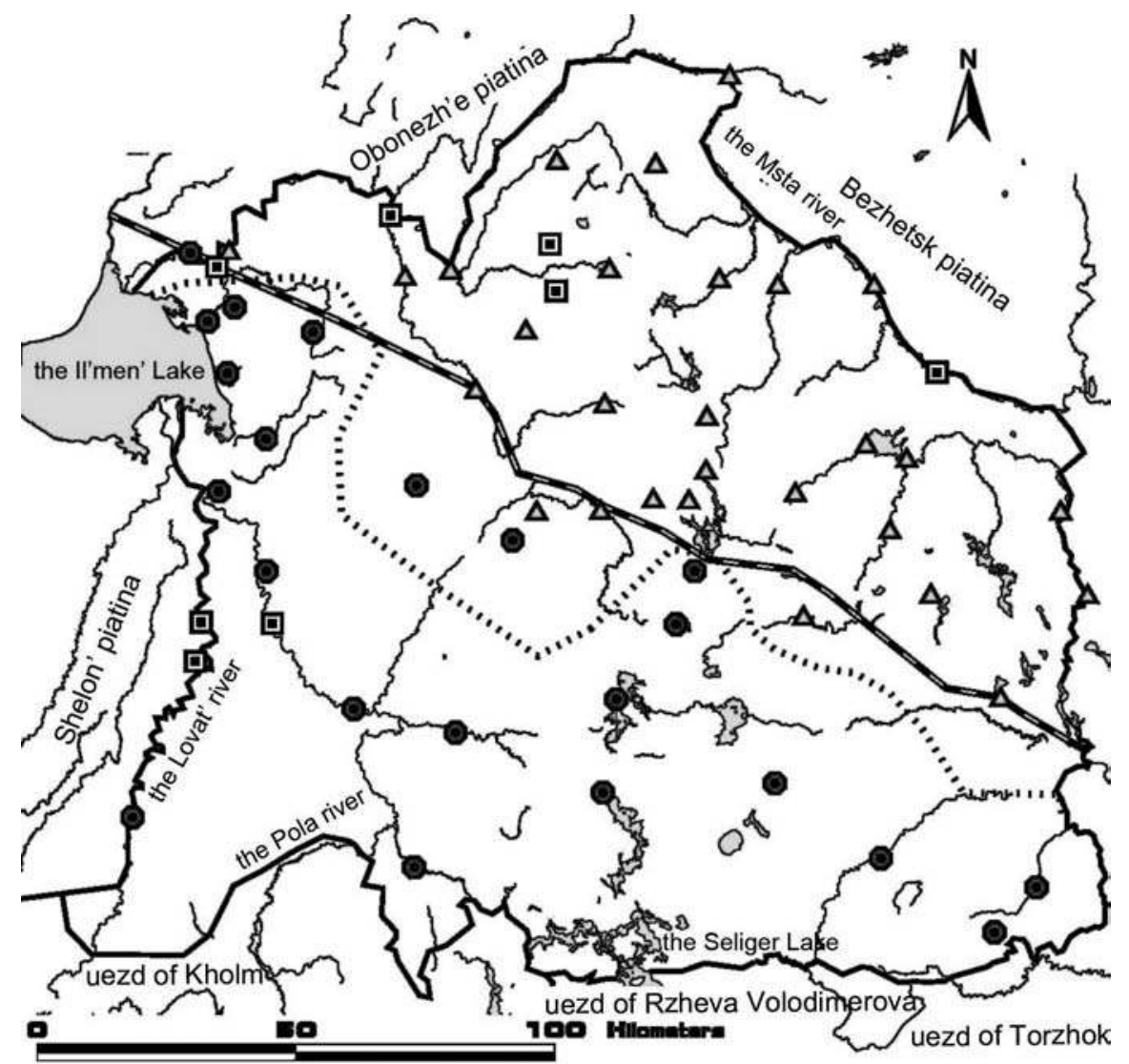

pogosty which are included in:
$\Delta$ the Gr.Morozov's area
- the Zh. Ryabchikov's area
口 no data
the Big Moscow Road the borders of polupiatinas
...... by sources of second half of the 16th century

$\mathbf{W}$ the border of Dereva piatina

Fig. 1. Division of the whole volume of describing work among Grigoriy Morozov and Zhikhar' Ryabchikov in the late 1530s in Dereva piatina. 


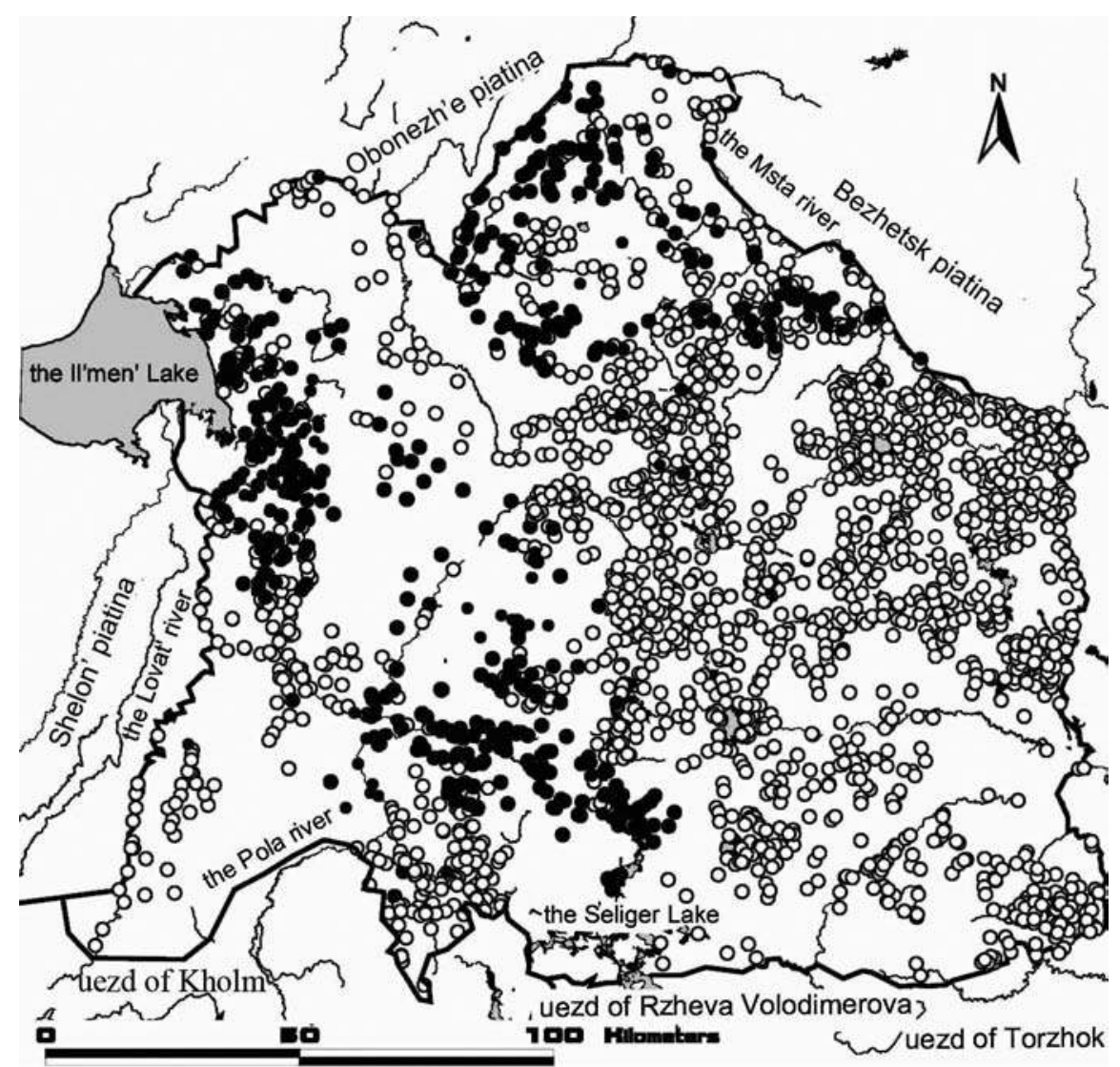

landlords' settlements which description was:

- preserved

- lost

(the settlements which description was lost are mapped by the data of the cadastre of 1499)

$\checkmark$ the border of Dereva piatina

Fig. 2. Degree of preservtion of the early 1540s scribes' books of landlords's settlements in Dereva piatina. 
on the other. The reliability of results obtained through such an analysis depends very strongly on the degree of accuracy and comprehensiveness achieved by the researcher in localizing the toponyms mentioned in the document. The methods and general results of the localization of place-names in the Dereva piatina of the $\mathrm{XV}^{\text {th }}-\mathrm{XVI}^{\text {th }}$ centuries have already been described in some detail. ${ }^{12}$ The analysis of the GI in these examples was applied to reconstruct the surveyors' field work in 14951496 as well as the structure of their field notes, which laid the basis for the Census book of Dereva piatina of $1499 .{ }^{13}$

Unfortunately researchers rather rarely bear in mind that there were never less than two, and usually three, stages in the history of any census book. ${ }^{14}$ Stage 1: a description of the land by the surveyors, which was connected, as a rule, with the way they travelled to the place or at least with their interrogation of local dwellers, who knew the facts the pistsy were after (the result was we could call their "field diary"); stage 2: an editor organized the information gathered in the field, according to the previously planned structure of the official document, and added data from other sources (this lead to the "draft" census book). Then usually followed stage 3: making a fair copy of the cadastre, a process which might change the respective places of different parts of the book without breaking its preset structure.

Field notes are practically unknown to scholars. They deal with the final product, which sums up all the stages mentioned above. That is why the assessment of a census book as historical source is traditionally limited to a study of the relevant manuscript: datation, arrangement, details of structure, etc. Reconstruction of the surveyor's "field notes" and methods thus becomes impossible. Meanwhile it is essential to find out the structure of the field notes, if one wants to understand all the possibilities this source has to offer to the historian.

Reconstructing the structure of field notes, nevertheless, isn't at all simple. It is impossible to determine differences in the order of data arrangement between a

12. N.V. Piotukh, A.A. Frolov, "Elektronnyi istoriko-geograficheskii atlas Derevskoi piatiny" [Electronic atlas of historical geography of Dereva piatina], Krug istochnikov: elektronnye resursy istoricheskoi informatiki. Trudy VIII konferencii Associacii "Istoriia i kompiuter" [A survey of sources: the electronic resources of informatic history. Proceedings of the VIII ${ }^{\text {th }}$ conference of the "History and computer" association] (M.-Barnaul, 2003), 198-233; Frolov, Piotukh, "Istoricheskii atlas Derevskoi piatiny po pistsovym knigam pis'ma 1495-1496 gg." [Historical atlas of the Dereva piatina according to the census books of 1495-1496], Vestnik RGNF [Bulletin of the RGNF], $\mathrm{n}^{\circ} 3$ (44), 2006, p. 50-60. A monography under almost the same title has been published in 2008 by the same authors: Frolov, Piotukh, Istoricheskii atlas Derevskoi piatiny Novgorodskoi zemli (po pistsovym knigam pis'ma 1495-1496 gg.) [Historical atlas of the Dereva piatina in Novgorod country according to the census books of 1495 1496], in 3 vol. (M.-SPb.: Al'ians-Arkheo, 2008).

13. Novgoroskie pistsovye knigi [Novgorod census-books], vol. I-II (SPb., 1859-1862).

14. Frolov, "Nekotorye voprosy istochnikovedeniia pistsovoi knigi Derevskoi piatiny pis'ma 1495-1496 gg." [A few problems concerning the sources of the census book of the Dereva piatina of 1495-1496], Drevniaia Ruś. Voprosy medievistiki, n 3, 2004, p. 55-69. 
"diary" and a "manuscript" on the basis of the manuscript alone. The GI seems to be the only key available to solve this problem. ${ }^{15}$

3. It has been noticed long ago that descriptions of settlements and deserted villages in the Census Book of the Dereva piatina of 1499 were arranged with a certain regularity. Material was grouped in chapters. Each chapter put together the surveys of lands depending from the same taxation centre. Lands within the chapter were grouped according to the categories of landowning. First lands of the State were described, then those of secular landlords, then the Novgorod Archbishop's estates, after that the Novgorod monasteries and finally - the freeholders [sing. svoezemets $\left.{ }^{16}\right]$. Within each category, the lands were listed under the names of their respective owners.

Let us consider the lands of one these owners in some detail : we find groups of settlements, the successive enumeration of which in the text corresponds with a certain sequence in space. We name such groups of settlements "links" (sing. zveno, a ring of a chain). Description of the estates of one landowner could consist of several such links. All settlements with a special status, e.g. the pogost center, the center of the estate with the landowner's mansion, deserted villages, newly founded settlements or villages divided between several landowners - which were called "shared villages") were outside this system. They were inserted at the very beginning or in the end of this landowner's estates description.

How can we determine the limits between "links," since the text of course does not mention them ? The demarcation between two different "links" appears when two settlements are described one after another, while in real space they are at a considerable distance from each other. We name such a gap a "seam" (shov). It's natural to suppose that in describing successive localities within each "link", the manuscript followed the order dictated by the itinerary of the surveyor, riding from one place to the next.

To find corroboration for this hypothesis, we shall focus on the mutual situation of such "links" within the borders of certain pogosty (Fig. 3). "Links" are arranged into complicated space "chains" (sing. tsepochka), and each "chain" consists of "links" belonging to different landowners. Conversely, it often happens that the "links" of a given estate belong to different space "chains."

Analyzing the way in which the position of given "links" in the manuscript corresponds to their situation in space allows us to deduce the methods applied, first by the surveyors, and after them by the compiler of the census book. In the field diary,

15. Frolov, "Metody raboty pistsov v Derevskoi piatine Novgorodskoi zemli vo vremia pis'ma 1495-1496 gg. i problema rekonstrukcii pistsovyh polevyh zapisei" [Working methods of the surveyors in Dereva piatina, in the country of Novgorod, at the time of the 1495-1496 survey, and how to reconstruct their field notes], in Iu.G. Alekseev and S.V. Strel'nikov, eds., Issledovaniia po istorii srednevekovoi Rusi [Research into medieval Russia history] (M.-SPb.: Al'ians-Arkheo, 2006), 299-318.

16. Svoezemets is a small landowner, who had retained his ownership since the times of Novgorod independence. 
data were arranged by pogosty, and, within each pogost, according to the itinerary of the surveying commission. Each itinerary started from the center of the pogost, where the church stood, and totalled an average 30 kilometers - corresponding possibly to the amount of work accomplished within one day (Fig. 3).

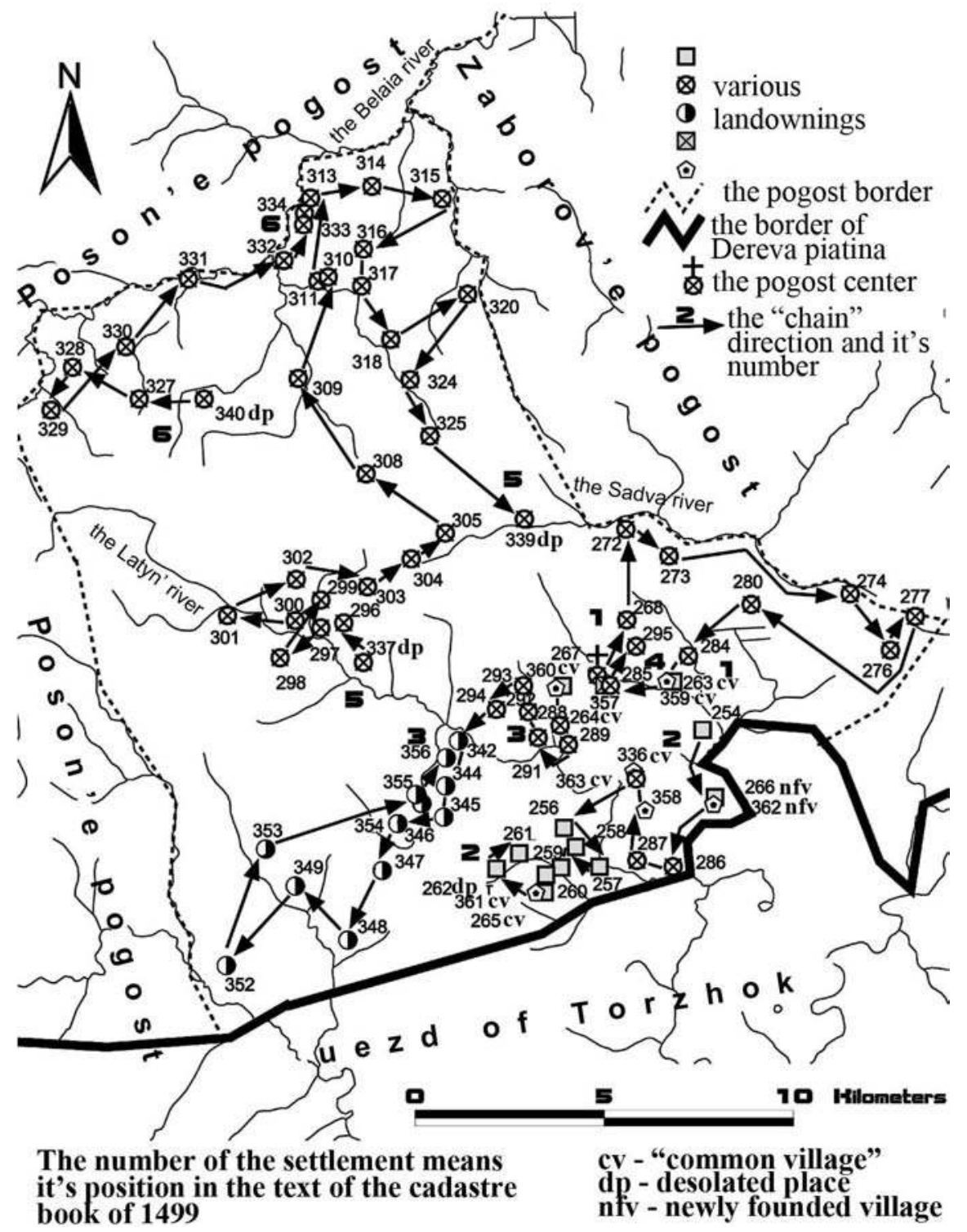

Fig. 3. Reconstruction of the scribe's roots on the territory of lasenovichi pogost of Dereva piatina in 1495-1496. 
The compiler of the census book copied, from the field diary, information concerning one landowner into its proper place in the manuscript, then information about the next landowner into the place allotted to him, and so forth. Thus he brought together fragments of text, which had been written down by surveyors riding on different routes (i.e. surveys belonging to different space "chains") (Fig. 4). Since

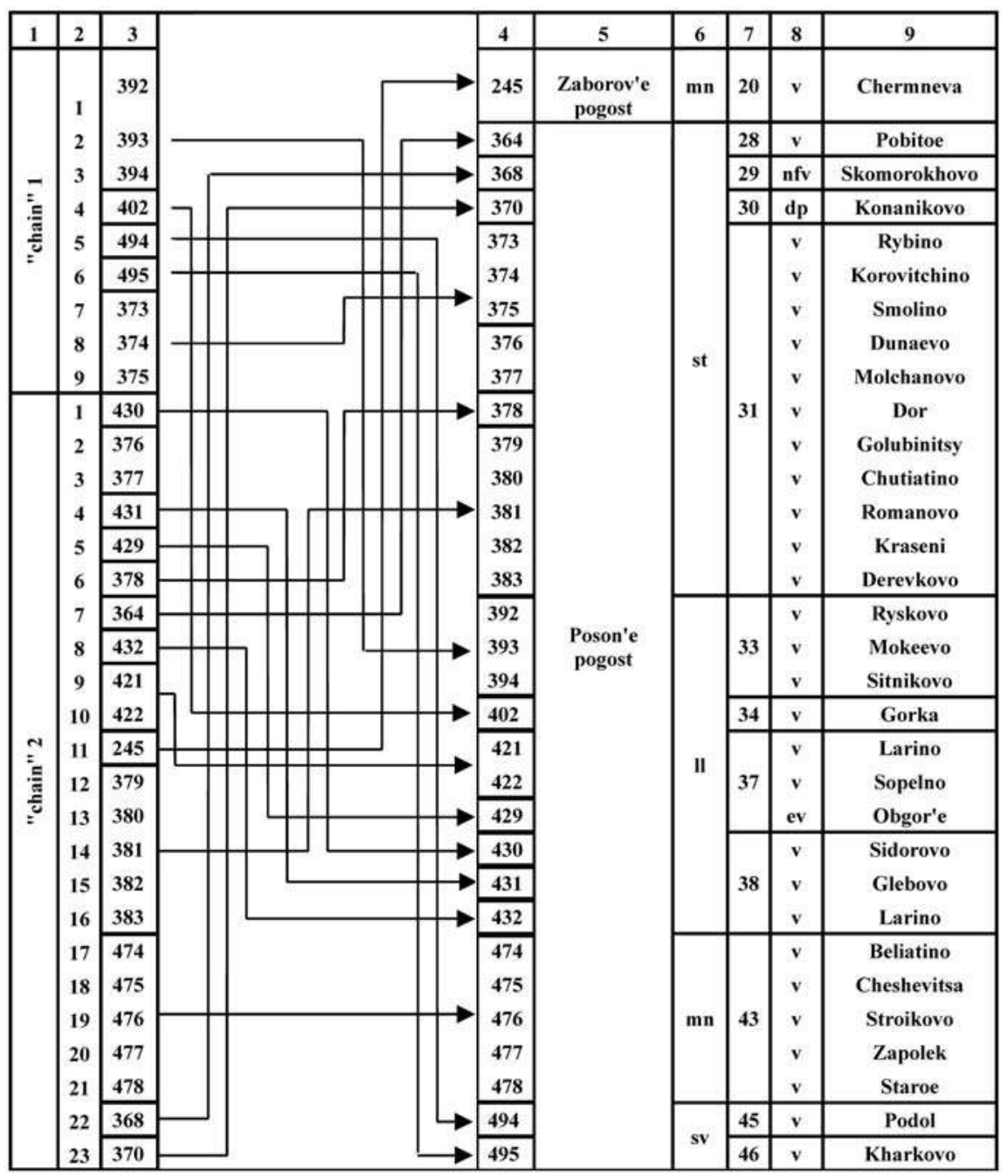

Fig. 4. Scheme of editor's work to organize information gathered in a field according to the previously planned structure of official document. The numbers of columns mean: 1-2. the elements that reflect position of the settlement in the "field diary" and determine it's structure: 1. the «chain» number; 2 . the settlement position in the «chain»; 3-8. the elements that reflect position of the settlement in the manuscript and determine it's structure: $3-4$. the settlement position in the manuscript; 5 . the rubric of the cadastre book; 6 . the category of landowning (st - state, 11 - landlord, $\mathrm{mn}$ - monastery, sv - "svoezemets"); 7. the landowning number; 8. the settlement status (dp - desolated place; ev - empty village; $\mathrm{nfv}$ - newly founded village; $\mathrm{v}$ - village); 9. toponim. The bold contour in the columns 3 and 4 is used to show «links». 
the compiler almost certainly copied these fragments according to their order of occurrence in the field diary, the disposition, in the final manuscript, of "links" coming from different chains but belonging to the same landowner is precisely what allows us to reconstruct the arrangement of the "chains" in the notes taken by the surveyor.

4. The same method of GI analysis enables us to reconstruct the order in which descriptions of whole areas appeared in the field diary. We can spot, in the manuscript, groups of neighbouring areas (usually, but not necessarily, coinciding with pogosty). The limits between these groups are, here again, "seams," on either side of which we find areas in real space very far from each other (Fig. 5). Now

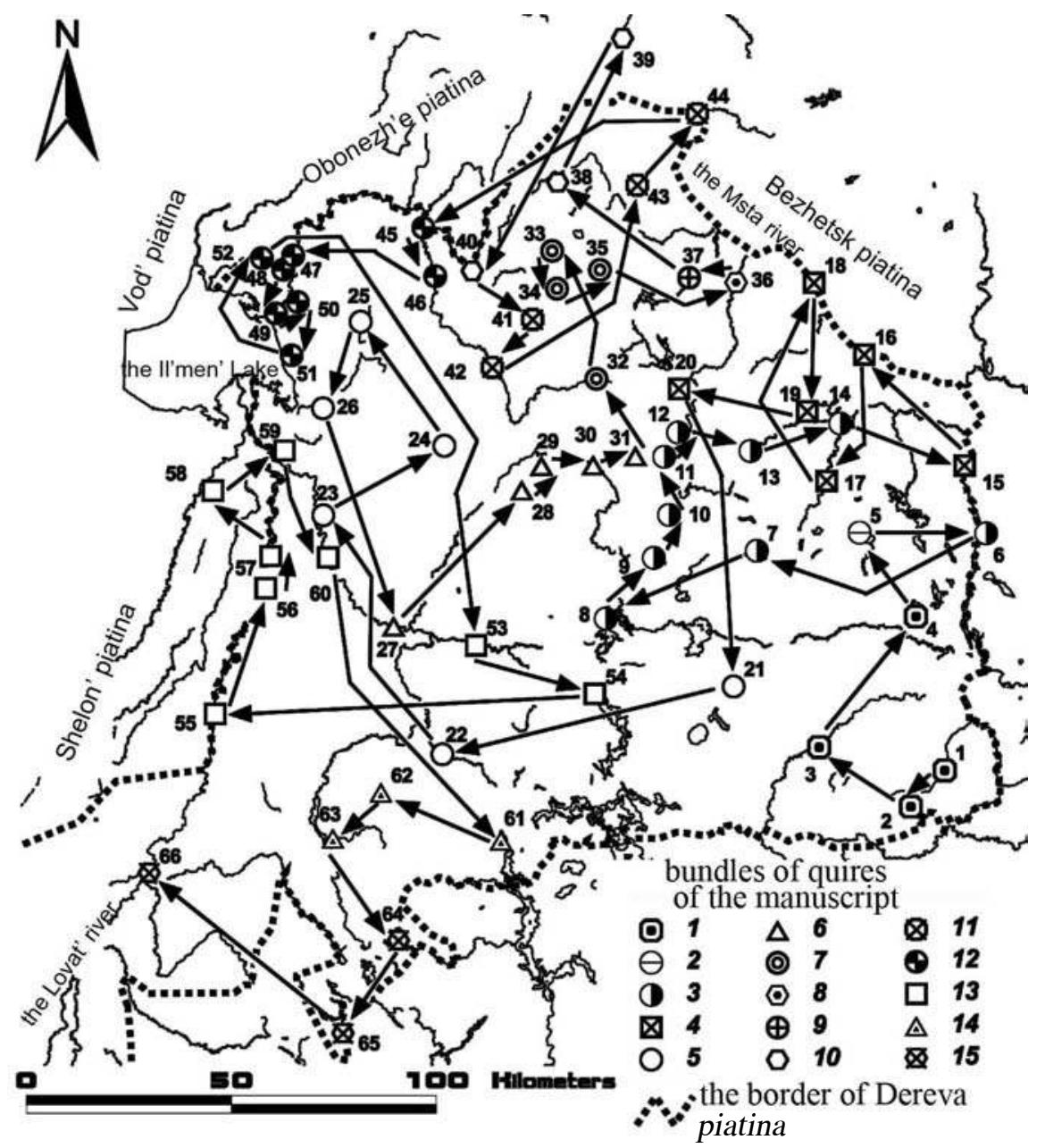

Fig. 5. Description of pogosty of Dereva piatina in the manuscript (the centers of pogosty are numerated in the order which they have in the cadastre book 1499). 
the manuscript consists of fifteen bundles of quires (sing. stat ${ }^{\prime i a) . ~ E a c h ~ b u n d l e ~}$ includes a number of headings of the census book. Almost all the bundles (apart from those which refer to the south-west of the piatina) contain the description of a compact group of pogosty, lying close together, while the "seams" occur in the end of one bundle and at the beginning of the next one. In all such cases we can safely conclude that in the bundles of quires we find the original order of appearance of the pogosty in the field diary, whereas the seams bear witness to the work of the compiler, who changed that order.

This does not apply to the bundles describing pogosty in the south-west of Dereva piatina: the areas which appear in the same bundle are often lying far apart. The reason for this is that the south-west was subjected to special fiscal and administrative regulations. Villages were ruled from one of three forts: Deman, Kursk and Kholm. That is why the compiler of the manuscript, while bringing the materials of the field diary in accordance with administrative structures, had to rehash the diary notes. Thus the order of the field diary was already broken by the manuscript compiler while editing field notes and drafting the first version of the census book. The order in which these pogosty were described in the field diary has been nevertheless successfully reconstructed after studying the routs followed by the surveyors.

Using the method described above, we can reconstruct the order of the pogosty in the field diary (Fig. 6). It appears that the surveyors of Dereva piatina at the end of $\mathrm{xv}^{\text {th }}$ century followed two separate routs, which suggests the existence of two surveying commissions. This, in turn, helps to explain the seeming contradiction between the large area surveyed (about 32100 square kilometers) and the speed of execution (480 to 490 calendar days at the most, according to historical sources). Granted that one space "chain" (less than 30 kilometers) usually corresponded to one working day of a surveyor, then from the area of the pogosty where all the "chains" have been well localized, we are able to deduce the average number of days needed per unit of square measure. Using this calculation, we find that the surveyors needed about 400 working days, i.e. about 200 days in the field for each of the two commissions, to survey the whole piatina. It could be entirely executed for the calendar period the whole campaign lasted.

In conclusion, we would like to point out that the possibilities of GI analysis, in particular when applied to research on the sources, extend far beyond the case of the Dereva piatina survey of 1495-1496. Each cadastral survey needs an individual approach. To solve the problems any given census book puts before us, the GI research must be adapted to the context. Its potential is truly unpredictable.

\section{"Novotorzhskaya Archeological Expedition" (autonomous non-commercial organization)}

npkfrolov@rambler.ru 


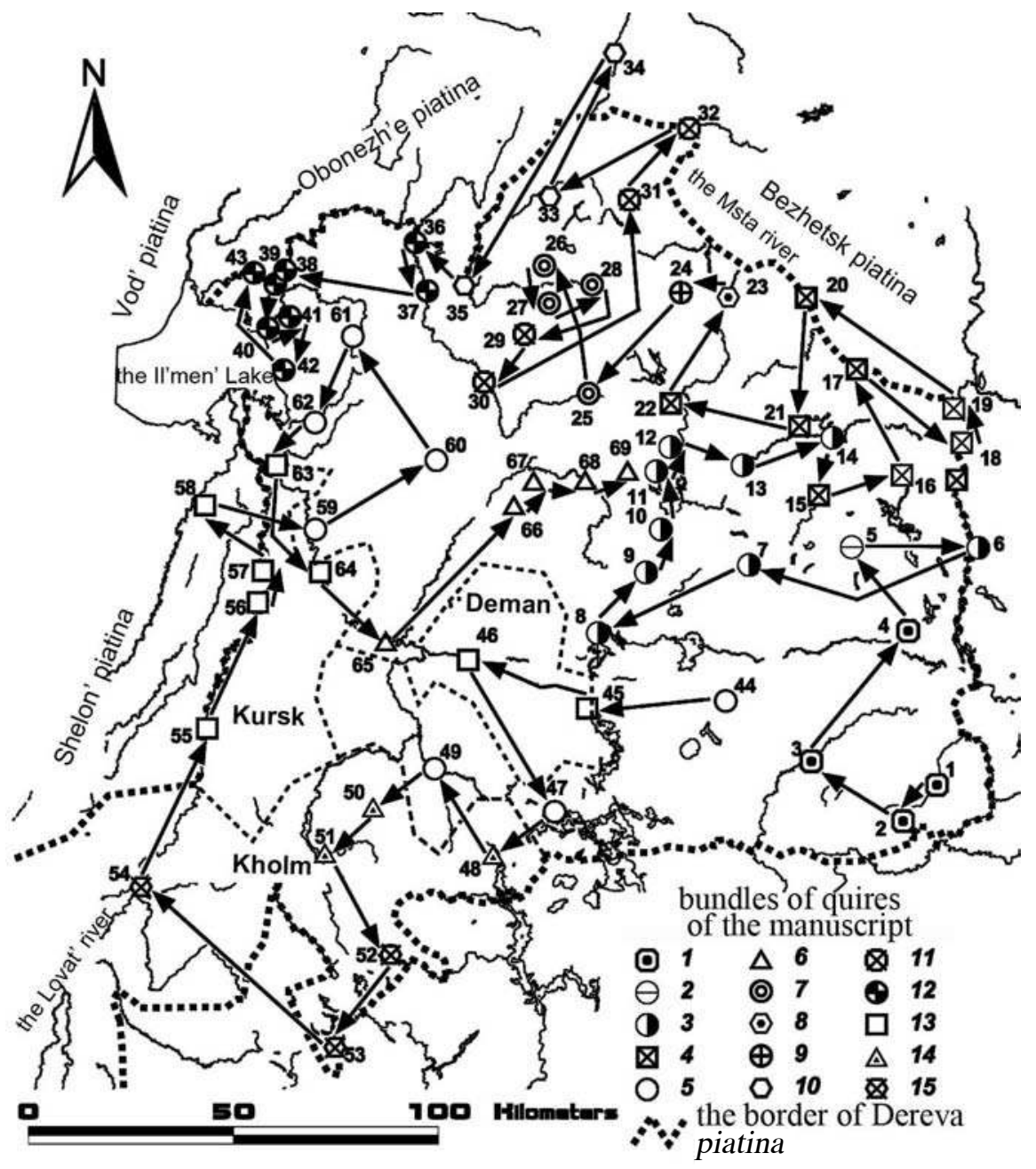

Fig. 6. Description of pogosty of Dereva piatina in the field diary (the centers of pogosty are numerated in the order which they had in the field diary 1495-1496 (reconstruction)). 